\title{
1 The deglaciation over Laurentian Fan:history of diatoms, IRD, ice and fresh water
}

2 Gil, Isabelle. M. ${ }^{1,2 *}$, Keigwin, Lloyd D. ${ }^{2}$, Abrantes, F. ${ }^{1}$

3

$4{ }^{1}$ IPMA - Portuguese Institute for the Seaand Atmosphere, Marine Geology and Geo-

5 resources division; Avenida de Brasilia 6,1449-006 Lisboa, Portugal

$6 \quad{ }^{2}$ CCMAR - Centre of Marine Sciences, Campus de Gambelas, 8005-139 Faro, Portugal

$7 \quad{ }^{3}$ WHOI - Woods Hole Oceanographic Institution, Geology \& Geophysics, 266 Woods Hole

8 Rd. - MS\# 08, Woods Hole, MA 02543-1050, USA.

$9 \quad$ *corresponding author: isabelle.gil@ipma.pt; phone: +351 213027089

(C) 2015. This manuscript version is made available under the Elsevier user license http://www.elsevier.com/open-access/userlicense/1.0/ 


\section{Abstract}

12 A high-resolution diatom census coupled with other proxy data from Laurentian Fan (LF)

13 provides a detailed description of the last deglaciation, bringing new insight to that period by

14 revealing directly the timing of sea-ice formation and melting. Cold events Heinrich Event 1

15 (H1) and the Younger Dryas (YD) were multiphase events. H1 ( 16.8-15.7 cal kyr BP) was

16 defined by a two-pulse release of icebergs promoting sea-ice formation. Melting of sea-ice

17 after $\mathrm{H} 1$ corresponds to a cold and fresh anomaly that may have kept the Bølling colder than

18 the Allerød. At 13.6 cal kyr BP, a cooling trend culminated with sea-ice formation, marking

19 the YD onset $(\sim 12.8$ cal kyr BP). The decrease in sea-ice $(\sim 12.2$ cal kyr BP) led to a YD

20 second phase characterized by very cold winters. However, the contribution of warm water

21 diatoms tends to increase at the same time and the YD gradual end ( 11.6 cal kyr BP)

22 contrasts with its abrupt end in Greenland ice cores. The YD cannot be regarded asan event

23 triggered by a freshwater input through the Laurentian Channelsince only one weak brief

24 input nearly 1000 yrs after itsonset is recorded. Very cold and cool conditions without ice

25 mark the following Preboreal. A northward heat flux between 10.8 and 10.2 cal kyr BP was

26 interrupted by the increased influence of coastal waters likely fed by inland melting. There

27 was no further development of sea-ice or ice-drift then.

\section{Introduction}

31 The North Atlantic exerts a strong influence on present day climate, with its 32 oceanographic changes affecting directly the climate of both sides of the basin(Dickson et al., 33 1996; Visbeck, 2002). Fresh water input and the presence of ice in the North Atlantic are 34 assumed to have played a major role during abrupt climate changes through their impact on 35 the thermohaline circulation - THC(Broecker et al., 1989; Rahmstorf, 2002), in particular 
during the deglaciation. However, there is no direct tracer for fresh water. Past fresh water input is inferred from oxygen isotope measurements on planktonic and benthic foraminifera, and the presence of melting icebergs is inferred from Ice Rafted Debris (IRD) in the sediments (Bond et al., 1992; Heinrich, 1988; Hemming, 2004). Furthermore, the absence of IRD does not necessarily mean the absence of ice, especially sea-ice. Regarding modeling experiments, the massive discharge of icebergs during Heinrich events (HE) is often simulated by a fresh water hosing (Flückiger et al., 2006; Liu et al., 2009; Prange et al., 2004), but those simulations do not accurately reflect fresh water pathways in the ocean (Condron and Winsor, 2011). Few studieshaveattemptedto simulate an iceberg discharge with progressive melting and transport (Jongma et al., 2012; Levine and Bigg, 2008; Roche et al., 2014).

Diatoms are siliceous microscopic algae with the ability to colonize diverse environments (including ice and fresh water) with diverse species. The diatoms preserved in marine sediments therefore reflect directly the properties of the surface water (photic zone), e.g. salinity, temperature and nutrients. They are also a major component of the phytoplankton community in polar environments associated with ice (Medlin and Priddle, 1990). Diatom assemblages can therefore offer an original description of the main climatic events of the last deglaciation over our study area, the Laurentian Fan (LF).

The few diatom records from the North Atlantic for the deglaciation are mainly from its equatorial and subtropical eastern margin (Romero et al., 2008; Stabell, 1986) or from the subpolar North Atlantic and Nordic Seas(Andersen et al., 2004; Knudsen et al., 2004; Koç Karpuz and Jansen, 1992; Koç et al., 1993). The only detailed deglacial marine record from the western side of the North Atlantic, on Bermuda Rise, is unfortunately limited in time because the diatoms are not preserved in the sediments after H1 (Gil et al., 2009).For this part of the North Atlantic, only one study from the Gulf of St Lawrence(Lapointe, 2000a) is 
61 available.Here, we provide a detailed description of the deglaciationin the north western

62 Atlantic with the aim of tracing directly the major forcings of the climate system that are

63 assumed to have played an important role: ice cover and the fresh water input.

64

65

66

67

68

69

70 appropriate proxy to describe the contrasted environments of the Slope Water System.

\section{Regional setting}

Laurentian Fan underlies part of the Slope Water System, where waters from subpolar and subtropical origin meet. Gatien (1976) described two distinct water zones of opposite characteristics: the Warm Slope Water Current, a bifurcation of the Gulf Stream and a wellmixed water found between 0 and $400 \mathrm{~m}$ depth, flowing primarily eastward; and the cold poorly mixed Labrador Slope Water flowing deeper and westward (Fig. 1). These water masses are juxtaposed and their borders and flows vary in response to changes in intensity of the Gulf Stream and of the Labrador Current (Pickart et al., 1999).A strong temperature and salinity front results therefore from the competing influence of these water massesalong the North wall of the Gulf Stream.In addition,brackish and fresh water from the Gulf of St Lawrence potentially overflows LF (Ohashi and Sheng, 2013). Finally, the site was located near the Laurentide Ice Sheet (LIS) margin duringthe Last Glacial Maximum (LGM) according to Dyke's reconstruction (2004).Diatoms (when preserved) appeartherefore as an

\section{3. Material and methods}

\section{$83 \quad 3.1$ Material and age model}


was retrieved from LF (Fig. 1) in July 1998 on board the R/V Oceanus from the western valley of $\mathrm{LF}($ Keigwin et al., 2005).

GGC14 age model is based on seven $\mathrm{AMS}^{14} \mathrm{C}$ dates on planktonic foraminifera(Keigwin et al., 2005). One additional ${ }^{14} \mathrm{C}$ date at $189 \mathrm{~cm}\left({ }^{14} \mathrm{C} 10800 \pm 70\right.$ years) was obtained from the National Ocean Sciences Accelerator Mass Spectrometer (NOSAMS) facility at Woods Hole Oceanographic Institutionto better define the Younger Dryas in this study. ${ }^{14} \mathrm{C}$ ages were calibrated using the INTCAL13 curve (Reimer et al., 2013) with a standard marine correction of 400 years. Age-depth modeling was elaborated using Clam 2.2 (Blaauw, 2010) R package. Ages were linearly interpolated at 95\% confidence ranges using Monte Carlo sampling (Fig. 2). The ages below the last dated level were extrapolated.

\subsection{Diatom analyses and ecology}

The core was sampled every $4 \mathrm{~cm}$ for diatom analyses. The samples were treated and counted following the method described in Gil et al. (2009). The total diatom abundances are reported as the median,minimum and maximum values (Fig. 3G).Diatom abundances were calculated in 89 samples and 63 had diatoms abundant enough to determine the assemblages. Three hundred diatom specimens (on a Chaetoceros free basis, as they are common) were identified to calculate the contribution of each diatom species. The minimum amount of 300 is required to assume that a contribution of $2 \%$ is significant with a confidence level of $95.4 \%$ (Galehouse, 1971).The diatomflora consists of 260 species(cf. supplementary dataincluding references for taxonomy) and a main environmental preference other than marine (e. g fresh water, brackish, ice, cold and warm) was attributed to severalspecies. The first step of diatom analysis was to comparethe GGC14 record with the modernsurface distribution of diatoms in the Gulf of St Lawrence and estuary (Lapointe, 
2000b). It was not conclusive: only one corein that study represented the open sea conditions

110 overlying GGC14 and most of herspecies listed inhabit brackish waters. There is no reference

111 to warm water diatoms reflecting the influence of the Gulf Streamasfound in GGC14.

112 Another option would beto apply a transfer function. Although diatomtransfer

113 functions for the northern North Atlantic (including the Labrador Sea) are available (De Sève,

114 1999; Jiang et al., 2001; Justwan and Koç, 2008; Koç Karpuz and Schrader, 1990), they do

115 not encompassour study area.No reliable transfer function for reconstructionis possible

116 without a calibration.

117 We settled onaprincipal component analysis (PCA) including a varimax rotation using

$118 \mathrm{R}$ (R core team, 2013). Species contributions of less than $2 \%$ were considered too rare for the

119 analysis (Imbrie and Kipp, 1971) and removed. However, for comparison purposes, a low

120 salinity diatom group was constituted with species considered brackish or freshwater even

121 though they scored less than $2 \%$ (cf. supplementary data).

122

3.3Ice Rafted Debris (IRD) and planktonic foraminifera $>150 \mu \mathrm{m}$

Bulk samples were dried, weighed, disaggregated in tap water and washed over a 63

$125 \mu \mathrm{m}$ mesh screen. The abundance of lithic grains (recognized to be IRD), the percentage of

126 Neogloboquadrina pachyderma (sinistral), and the number of planktonic foraminifera was

127 determined in the $>150 \mu \mathrm{m}$ fraction(in 99 samples for the IRD and 74 for foraminifera

128 counts). When either the IRD or the foraminifera were very abundant, the samples were split

129 before counting. Relative abundances of IRD components (quartz, hematite stained quartz and

130 detrital carbonate grains) were estimated on a semi-quantitative basis.

132 4. Results

133 4.1 The diatom record: Principal Component Analysis 
135 of the species that contributed to their construction(Fig. 4). The remaining species with a 136 contribution $>2 \%$ in more than one sample are plotted in Figure 5.

137 For the PCA, a total of 42 diatom entities (Table 1) were used and the eigenvalues 138 indicate that $92.23 \%$ of the variance is explained by fivefactors. Factors 3 and 4 (made of 139 species that were particularly abundant at a specific time and not all along the core) explain 140 less than $7 \%$ of the variance.

141 Factor 1 (Fig. 3A) is primarily made by Fragilariopsis oceanica (Cleve) Hasle and 142 secondarily by Delphineis surirella (Ehrenberg) Andrews. The former is known to thrive in 143 ice and drifting ice and/or very cold environments (Hasle et al., 1996; Jiang et al., 2001;

144 Justwan and Koç, 2008; Koç Karpuz and Schrader, 1990; Medlin and Priddle, 1990), whereas 145 the second is found in "cool to temperate seas" (Andrews, 1981). This factor reflects cold 146 conditions clearly dominated by ice.

147 Odontella aurita (Lyngbye) Agardh and Thalassiosira gravida / antarctica var.

148 borealis Cleve resting spores contributed negatively to factor 2 (Fig. 3B). We refer to

149 Thalassiosira gravida / antarctica var. borealis because there is some confusion regarding the

150 nomenclature of Thalassiosira gravida Cleve. Although reference studies mention

151 Thalassiosira gravida resting spores (De Sève, 1999; Justwan and Koç, 2008; Koç Karpuz

152 and Schrader, 1990), this species is not supposed to form any(Syvertsen (1977) and cf.

153 discussion in Hasle et al.(1996)). We choose to indicate both names as previously done (Jiang

154 et al., 2001). O. aurita is regarded as a cosmopolitan species (Hasle et al., 1996), but this

155 species is present in first year ice and is known to appear in monospecific blooms after 156 particularly severe winters (Melnikov et al., 2002). It flourishes between $-1.5^{\circ} \mathrm{C}$ and $2^{\circ} \mathrm{C}$

157 (Baars, 1985)and is abundant in fast-ice (McMinn et al., 2008). The formation of resting

158 sporesof T. gravida / antarctica var. borealis implies the degradation of its survival 
conditions(McQuoid and Hobson, 1996), which in this case, might be the rapid establishment

160 of very cold conditionslikely expressing a strong seasonal contrast. The score of factor 2 is

161 reversed to make clearer that its interpretation is based on negative scores (Fig. 3B).

162 Factor 3(Fig. 3C) is constructed by the eurythermal and euryhaline diatom

163 speciesParalia sulcata(Ehrenberg) and Thalassionema nitzschioides(Grunow)

164 Mereschkowsky(Smayda, 1958). In the Nordic Seas, these species belong to the Norwegian-

165 Atlantic Current assemblage influenced by Atlanticwaters, with salinitiesup to 34.9 andsea

166 surface temperature above $3^{\circ} \mathrm{C}($ Koç Karpuz and Schrader, 1990).P. sulcata is also a

167 meroplanktonic species common in coastal plankton (Hasle et al., 1996) and isa factor on its

168 own in Lapointe's study (2000b) where it corresponds to coastal nutrient rich waters (summer

169 temperature of $10-12^{\circ} \mathrm{C}$ and salinities of 26-29). This factor represents therefore coastal -

170 temperate waters, an environment probably affected by rapid changes in salinity and

171 temperature.

172 Thalassiosira oestrupii (Ostenfeld) Hasle constitutes factor 4. This species is found in

173 warm to temperate waters (Hasle et al., 1996) and is clearly associated with warm Atlantic

174 waters (Jiang et al., 2001; Justwan and Koç, 2008; Koç Karpuz and Schrader, 1990; Kohly,

175 1998; Maynard, 1976).

176 Finally, the opposite contribution of $D$. surirella(positive) and Detonula confervacea

177 (Cleve) (negative) made factor 5.D. surirellais a benthic speciesassociated withcool to

178 temperate waters(Andrews, 1981) and is common in marine and brackish coastal waters

179 (Hendey, 1964).D. confervacea is an Arctic species that also appears in temperate waters

180 during the cold season (Hasle, 1973). It is also reported from the water column associated

181 with the sea-ice and in the ice itself (Ikeya et al., 2001; Robineau et al., 1997). Extreme low

182 temperatures favor this speciesthat tolerates lower salinities, with a faster growth at a salinity

183 of 25 (McQuoid, 2005)but not surviving salinities below 8 or temperatures above $15^{\circ} \mathrm{C}$ 
184 (Guillard and Ryther, 1962).Cultures of this species show that a warming (from 2 to $7^{\circ} \mathrm{C}$ )

185 increased its mean growth rate (Holt and Smayda, 1974).Factor 5 represents cool conditions, 186 with negative extremespossibly indicating decreased surface salinity.

187 The absence in Lapointe's study (2000b) of some diatom species constructing the

188 GGC14 PCA factors (as F. oceanica, D. surirella, T. oestrupii, D. confervacea) highlights the 189 environmental and spatial variability of this region.

\subsection{Diatom abundance, species contribution and factors loading}

192 The record begins at $\sim 19$ cal kyr BP (Fig. 3G) and extremely low diatom abundances

193 are found in the red-clay sediments (dotted box in Fig. 3 and 4) until about 17.6 cal kyr BP.

194 Such red and brownsediments appear to be characteristic of the LGM over LFand along the

195 Scotian margin and preceded H1(Keigwin and Jones, 1995; Piper and Skene, 1998).

196 From $16.1 \mathrm{cal}$ kyr BP, the diatom abundances started to increase and diatoms were

197 still abundant until 14.1 cal kyr BP. Then, and until 12.8cal kyr BP, abundances were

198 relatively low before rising and reaching their maximum abundance close to $12 \mathrm{cal} \mathrm{kyr}$ BP.

199 After that, the abundances diminished constantly and reached low values towards the end of

200 the record $(\sim 9.4$ cal kyr BP).

201 The ice record (factor 1 in Fig. 3A explaining $65.47 \%$ of the variance) is characterized 202 by two general decreases: from the beginning of the record until 13.9cal kyr BP and from 12.7

203 to 9 cal kyr BP (accentuated minima at $\sim 12.4$ and 11.8 cal kyr BP). The minima at $\sim 16.3$,

$20415.7,14.4$ and 13.7 cal kyr BP separate the highest levels.Factor $2(11.76 \%$ of the

205 variance)was most notably negative between 15.6 and 13.9 cal kyr BP (less $\sim 15$ cal kyr BP)

206 and increasingly negative from 13.7 to $10.8 \mathrm{cal} \mathrm{kyr} \mathrm{BP}$, when the trend was reversed. $O$.

207 aurita (Fig. 4D) explains the factor variability between 15.6 and 15 cal kyr BP and at $\sim 12.4$

208 cal kyr BP.The variability of factor $3(6.44 \%$ of the variance; Fig. 3C)is limited and the most 
relevant feature is its score increase from 11.7 to 9 cal kyr BP.Factor 4 indicates $(5 \%$ of the

210 variance)warmer conditions starting around 14.6 cal kyr BP (Fig. 3D) that lingered until

$211 \sim 12.8$ cal kyr BP, except notably $\sim 14$ cal kyr BP. Then, the conditions started to warm slowly

212 again from 12.2 to $10.5 \mathrm{cal}$ kyr BP before decreasing.Factor 5explains littleof the variance

213 (3.56\%). The most distinctive features are related to $D$. surirella with higher contributions at

$21416.3, \sim 13.9$ and 14.8 cal kyr BP. D. confervacea contributed clearly to the variability recorded

215 between 12.2 and 11.7 and at $\sim 13.9$ cal kyr BP. Finally, the contribution of low salinity

216 diatoms wasmostly significant ( $>2 \%$ ) from 17.2 to 14 cal kyr BP (Fig. 3F), except principally

217 around $15.4 \mathrm{cal} \mathrm{kyr} \mathrm{BP.}$

218

219

\subsection{The IRD and the $N$. pachyderma (s) records}

Grains of quartz and detrital carbonate $>150 \mu \mathrm{m}$, considered to be IRD started to appear in the sediment at 18.2cal kyr BP, with low values( 10/g)(Fig. 3H, Fig. 6). The abundances rose at $16.8 \mathrm{cal} \mathrm{kyr} \mathrm{BP}(5449 / \mathrm{g})$, initiating the period of highest abundances that lasted 500 years. This interval, referred to here as pulse A, has the only significant detrital carbonate representation, which we estimate to be about $20 \%$ of the grains $>150 \mu \mathrm{m}$, between about 376 and $382 \mathrm{~cm}$ (Fig. 6). Hematite stained quartz never dominates the IRD, but reaches $40-45 \%$ at the beginning of $\mathrm{H} 1 \mathrm{~A}$, and $40-50 \%$ at the end of H1B. Otherwise, the hematitestained grains range from nearly absent to $30 \%$ of the lithic fraction. TotalIRD registered low abundances between 16.3 and 15.9cal kyr BP ( 500/g), before a second period of high abundance from 15.9 to $15.7 \mathrm{cal}$ kyr BP. IRD abundances were extremely low again, until the mid-Allerød to the mid-YD (13.4 to $12.2 \mathrm{cal} \mathrm{kyr} \mathrm{BP).}$

The $N$. pachyderma (s) record (Fig. 3J) covers the period between $\sim 11.3$ and $18.1 \mathrm{cal}$

232 kyr BP. The highest values(between 60 and 100\%) arerecorded during the intervals 18.1-15.5

233 (except at 16.5 and 15.9) and 12.1-12.7 cal kyr BP. From 14.8 to 13.8 cal kyr BP, the 
contribution increased from 15 to 53\%, between periods of minimum values (15.2-14.8 and

$235 \quad 13.3-12.8$ cal kyr BP).

236

237

238

\section{Discussion}

\subsection{Anatomy of Heinrich Event 1 on Laurentian Fan}

IRD in marine sediments helps to identify the HE and define themsensus stricto.

241 However, our record reveals a succession of oceanographic changes far beyond the IRD

242 deposits, butdirectly associated with the iceberg discharges and melting. H1 had therefore a

243 longer temporal expression than the simple record of IRD and this period fitswithin the range

244 of the "Mystery Interval" (Denton, 2006).In GGC14,H1 is indicated by two distinct releases

245 of IRD at LF: the first, pulse A (H1A) between 16.8 and $16.3 \mathrm{cal}$ kyr BP, and a second IRD

246 pulse B (H1B) from 15.9 to $15.7 \mathrm{cal}$ kyr BP (Fig. 3H).GGC14 IRD deposits associated with

$247 \mathrm{H} 1$ are about $32 \mathrm{~cm}$ thick (12 $\mathrm{cm}$ for H1A alone). This is thicker than in nearby cores

248 (deGelleke et al., 2013), but is the same order of magnitude if only H1A is considered.

249 GGC14 can also present higher sedimentation rates. Because of its distinctive detrital

250 carbonate component, H1A is likelyrelated toa detrital carbonate 1 (DC-1) interval previously

251 interpreted to indicate a dominant Labrador Current supply of icebergs that later mixed with

252 icebergs from the Gulf of St Lawrence over LF (Piper and Skene, 1998). Hematite stained

253 quartz grains indicating a supply from the Gulf of St Lawrence are only notably recorded at

254 the beginning and at the end of H1. The two main IRD pulses in our LF record are consistent

255 with our previous work on Bermuda Rise indicating that $\mathrm{H} 1$ is made of more than a single

256 pulse of icebergs (Gil et al., 2009).

257 H1 Awas longer ( $\sim 500 \mathrm{yrs})$ and has about twice as many grains per gram as H1B. The

258 maximum in IRD seems to match a small but distinct warming of the NGRIP record which 
we use here to provide a Northern Hemisphere context to our results(Fig. 3L). H1 Awas

260 preceded by a relative higher contribution in low salinity water diatoms (Fig. 3F), but their

261 contribution rapidly decreased, while cooland coastalwaters prevailed (Fig. 3E). The total

262 diatom abundance also increased progressively. H1A was followed by a $\sim 200$ yrs period of

263 reduced iceberg discharge. During this pause, ice and cool coastal low salinity diatoms

264 increased, marking the development of sea-ice. The NGRIP record alsoindicates a cooling. At

265 the same time, there was no low salinity water advected by cold core rings over the Bermuda

266 Rise or resulting from in situ melting icebergs (Gil et al., 2010; 2009), supporting the pause in

267 the iceberg discharge.

268 During H1B ( 200 yrs), IRD abundances were lower and ice diatoms clearly

269 dominated. N. pachyderma (s) (Fig. 3J) recorded its highest abundance. Perhaps at that time

270 pervasive sea-ice and icebergs coexisted. Abundances of low salinity diatoms were highly

271 variable during the event, but are relatively more abundant shortly before H1B.

272 Similarly to LF, two peaks in IRD are also recorded at the Northwest European

273 margin (Walden et al., 2006) and at the Portuguese margin precisely at 17.5 and 16 cal kyr

274 BP(Bard et al., 2000). The variability of the Iberian continental vegetation also points to two

275 distinct phases during H1: the first was characterized by cold and wet conditions while the

276 second corresponded to less cold conditions and increased dryness (Naughton et al., 2009).

277 The west-east variability of these records also suggests a differential spatial melting of

278 icebergs and IRD release.The IRD pulses over LF are accompanied by low $\delta^{18} \mathrm{O}$ and are

279 interpreted as a freshening (Keigwin et al., 2005), but the contribution of the fresh water

280 diatoms does not clearly mark the pulses. The formation of sea-ice might rather explain the

281 low $\delta^{18} \mathrm{O}$ values, as proposed by Hillaire-Marcel and de Vernal (2008). Indeed, the diatom

282 record indicates the development of sea-ice in between the pulses and during H1B. During

$283 \mathrm{H} 1 \mathrm{~A}$, the diatoms were too few (due to numerous IRD and a minor fraction of fine 
284 sedimentpossibly containing diatoms) to obtain a statistically reliable result in some samples.

285 A large volume of sediment would have been necessary to check if those samples would also

286 contain ice diatoms, as suggested by Sancetta (1992).

287 The ice diatom assemblage culminated between $\sim 16.2$ and 15.8 cal kyr BP, roughly

288 between the two IRD pulses, and its decline by the end of H1 corresponded to the clear rise of

289 the diatom O. aurita (Fig. 4D). It seems to be the response to the end of the iceberg discharge

290 and evidences the first step of sea-ice waning. The thinning of the sea-ice and the extremely

291 low abundance of IRD suggest that the strong cooling sustaining the sea-ice and sea-ice

292 formation was likely imposed by icebergs. The sudden decrease of $O$. aurita $(\sim 15.6 \mathrm{cal} \mathrm{kyr}$

293 BP) is compensated by the rise in low salinity diatoms from $\sim 15.3$ to 14.6 cal kyr BP (Fig.

294 3F), likely representing the major melting of this sea-ice previously formed, even though

295 some sea-ice is still likely present. Thus from the diatom perspective, the freshening signal

296 resulting from $\mathrm{H} 1$ appears after the event.HE are often only considered as a low salinity

297 anomaly in the North Atlantic when it is principally a strong cooling promoting sea-ice

298 formation according to the diatom record (Fig. 3A), at least at this site.

299 Finally, $\mathrm{Mg} / \mathrm{Ca}$ inferred temperatures (calcification temperature - CT) in this core(Fig.

300 3I) indicate a gradual warming (Obbink et al., 2010) that culminates at 16.6 cal kyr BP during

$301 \mathrm{H} 1 \mathrm{~A}$. That result contrasts with the high variability of the diatom record, the low $\delta^{18} \mathrm{O}$ of $N$.

302 pachyderma (s), andthe high percentage of that species $(>90 \%)$ during $\mathrm{H} 1$. These results are

303 consistent withprevious studies thatshow very low temperatures associated with drifting ice

304 and sea-icecan possibly bias $N$. pachyderma (s)calcification temperatures that are based on

$305 \mathrm{Mg} / \mathrm{Ca}($ Kozdon et al., 2009; Meland et al., 2006).

306

$307 \quad 5.2$ The Bølling, the Older Dryas and the Allerød 
309 diatomT. oestrupii (Fig. 3D and 4G). Their variability fit the evolution of the NGRIP $\delta^{18} \mathrm{O}$

310 record (Rasmussen et al., 2006)within dating errorsand calcification temperatures

311 (CT)(Obbink et al., 2010)(Fig. 3I). Based on diatoms, the Allerød period appears relatively

312 warmer than the Bølling, while the ice core and CT records indicate the opposite. The lack of

313 significant presence of low salinity water/meltwater during the Allerød might explain such a

314 difference by favoring a strong mode of the THC.Indeed, the onset of the Bølling followed the

315 important melting of sea-ice and a strong seasonal contrast prevailed during the Bølling, with

316 the near freezing cold water foraminifera N. pachyderma (s)still abundant (Fig. 3J). The role

317 of meltwater in the transition to the Bølling has already been studied through modeling

318 experiments (Liu et al., 2009) and the results revealed that the abrupt warming would be due

319 to the cessation of the meltwater flux (a sudden shut-off at $14.67 \mathrm{cal} \mathrm{kyr} \mathrm{BP}$ or a linear

320 decrease to 0 at 14.2 cal kyr BP) and not to the resumption of the Atlantic Meridional

321 Overturning Circulation (AMOC). Our results support the idea that the presence of meltwater

322 modulates the intensity of the warming. The presence of low salinity water during the Bølling

323 at our site is not necessarily contradictory with the modeling results (Liu et al., 2009),

324 depending on the sensitivity of the model they used to fresh water forcingand where the fresh

325 water was prescribed.

326 The Bølling and the Allerød are separated by a decrease in the warm water factor,

327 which corresponds also to an increase in ice, coastal and low salinity diatoms centered $\sim 14$ cal

328 kyr BP(Fig. 3ACEF). Mg/Ca inferred salinity in GGC14 also indicates a fresh water

329 discharge (Obbink et al., 2010). Oddly, N. pachyderma (s) was not outstandingly more

330 represented (Fig. 3J), but itscontributions was still significant ( 20\%). By the same time, a

331 major calving ice retreat event occurred (Shaw et al., 2006). This freshening and interruption

332 of the warming is known in terrestrial records as the Older Dryas $\left(12000-11800{ }^{14} \mathrm{C} \mathrm{BP}\right.$ in 
333 Mangerud et al. (1974)). Previous high-resolution studies advocated that the abrupt cooling of

334 the Older Dryas would correspond to the meltwater pulse 1a (MWP 1a) (Stanford et al.,

335 2006), while coral measurements from Tahiti indicate that the MWP1a was simultaneous to

336 the Bølling onset (Deschamps et al., 2012).If the hypothesis that meltwater from the LIS

337 would have had contributed to the MWP 1a is valid (Carlson et al., 2007), the larger input

338 would have precede the Bølling although low salinity is still significantly present over the site

339 during the second half of the Bølling and the Older Dryas. Without a better characterization of

340 the contribution of the LIS to MWP 1a, it is not possible to indicate the timing of its imprints

341 over LF sediments.

342 From the Older Dryas to the Allerød, the contribution of low salinity diatoms dropped

343 and clearly marks the return to warmer conditions, with a maximum warming at $\sim 13.8 \mathrm{cal}$ kyr 344 BP.

\subsection{The Younger Dryas}

The YD was preceeded by mid-Allerød ( 13.8cal kyr BP) changes including increased

348 abundance of ice related diatoms and IRD, and a decreased contribution of warm water

349 diatoms. Broecker et al. (2010)already pointed out that the slow onset of the YD showed in

350 numerous records argues for a non-catastrophic event. The elevated contribution of ice-related

351 diatoms between 12.7 and 12.2cal kyr BP clearly marked the onset of the YD, while from

$352 \sim 12.2 \mathrm{k}$ a slow increase in warm water diatoms (Fig. 3D)andD. confervacea(Fig. 4H) marked

353 a second phase (12.4 - 11.6 cal kyr BP).

354 The initial peak in ice related diatoms is associated with few IRD and very cold waters

355 testifying the presence of some icebergs. These icebergs could have been brought through the

356 Laurentian Channel and / or a stronger Labrador Current and promoted sea-ice formation, as

357 during H1.A major contribution of O. aurita(12.6 - 12.4cal kyr BP)followed, similarly to the 
diatom succession observed during and after H1.Contrary to H1, there was no evidence for a

359 low salinity anomaly afterwards. Instead, the concomitant increase in warm and cool water

360 diatoms (including D. confervacea) points to milder conditions and may reflect also a

361 seasonal contrast.A similar warming trend is recorded on the west side of the Laurentian

362 Channel and on the Scotian Shelf(Levac et al., 2015). Relatively warmer waters would also

363 favor an increased growth rate of D. confervacea(Holt and Smayda, 1974). The tolerance of

364 D. confervacea to lower salinities, its affinities with sea-ice and its prevalence during the YD

365 phase 2is relevant since the YD has been hypothesized to result from a fresh water outburst

366 from Lake Agassiz into the North Atlantic preventing the formation of North Atlantic Deep

367 Water - NADW(Broecker et al., 1989). With only one brief significant signal of low salinity

368 water input nearly 1000 yrs after the YD onset (Fig. 3F), the low salinity anomaly cannot be

369 considered a striking feature ofthe YDin the slope water system.Our record is consistent with

370 the interpretation of previous dinocyst records(deVernal et al., 1996; Levac et al., 2015): low

371 temperatures, thin sea-ice cover and reduced meltwater from the outlet of the Gulf of St

372 Lawrence into the Atlantic.This interpretation, however, contradicts the resultsobtained from

$373 \mathrm{Mg} / \mathrm{Ca}$ on foraminifera(Carlson et al., 2007) that might have been strongly influenced by the

374 development of sea-ice and the presence of icebergs (notably during phase 1).The potential

375 seasonalsea-iceformed during the second phase of the YD differs from the one previously

376 formed (factor 1) by its thickness and persistence. The mix of warm and cold conditions

377 during the second phase of the YD suggests indeed that the thin sea-ice was related to the

378 episodic presence of very cold waters. The high abundance of $D$. confervacea associated with

379 the decline of thin sea-ice and enhanced primary productivity by the end of the event is also

380 detected in a Newfoundland shallow coastal site(Pearce et al., 2013; 2014).

381 The dual feature of the YDis present elsewhere in several high-resolution records,

382 principally from lakes(Bakke et al., 2009; Brauer et al., 2008; Neugebauer et al., 2012), but 
383 also inoceanic sites such asCariaco basin(Lea et al., 2003)or off Northwest Africa (Cole et al.,

384 2009). These studies point to an early YD (first phase) that was windier off Northwest Africa

385 and colderover the Cariaco basin. Over LF, the conditions were also colder, with more

386 abundant ice related diatoms attesting the development of seasonal sea-ice. Such conditions

387 would have shifted the Inter Tropical Convergence Zone southward -ITCZ (Chiang and Bitz,

388 2005) and it would explain the Northwest Africa and Cariaco records. The decrease of $D$.

389 confervacea clearly marks the end of the YD. An outstanding contribution of the warm

390 waterdiatoms does not mark the end of the event as it would be expected. Instead, this

391 assemblage presents a steady evolution contrasting with the warming indicated by the NGRIP

392 record.

393

$394 \quad 5.4$ The early Holocene

395 The Holocene record of GGC14 confirms the continuous decline of ice. Very cold and

396 cool conditions prevailed until $\sim 10.8 \mathrm{cal}$ kyr BP. These conditions could have been established

397 rapidly (cf. section 4.1) and represent in partthe Preboreal Oscillation cold event (Hald and

398 Hagen, 1998).After $\sim 10.8 \mathrm{cal}$ kyr BP, the waters warmed and the influence of coastal and

399 temperate watersconditions continued to progress, even more from $\sim 10.2$ cal kyr BP when the

400 waters cooled again. The warming between $\sim 10.8$ and 10.2 cal kyr BP supports a stronger

401 AMOC with a northward penetration of the heat fluxinitiating the retreat of the ice-margin at

402 Disko Bugt on theWestern Greenland Ice sheet (Kelley et al., 2013) and getting Frobisher Bay

403 (Labrador Sea) ice-free from at least 10.5 to 10.2 cal kyr BP(Miller and Kaufman, 1990). This

404 warming was equivalent to the Bølling warming (Fig. 3D). The halt of the heat flux and

405 northern melting is likelydue to the routing of some LIS meltwater to the Gulf of Mexico

406 (Aharon, 2003; Flower and Kennett, 1990; Poore et al., 2003; Rasmussen and Thomsen,

407 2012), however the evidences for such routing are missing in some cores of the region 
408 (Marchitto and Wei (1995) and references herein).The progression of the coastal water over

409 LF suggests also that the cooling was related to the melting of ice on land that started after

$410 \sim 13$ cal kyr BP(Shaw et al., 2006) and especially after 10 cal kyr BP(Shaw et al., 2002).

411 These increased coastal waters did not bring ice or lead to very cold conditions and, even if

412 the timing is similar, there is no evidence for a catastrophic event as the Gold Cove event

413 (Kaufman et al., 1993). Finally, theincreased volume of coastal- temperate waters was

414 deduced from the high contribution of P.sulcata that is also found in a shallower $(1381 \mathrm{~m})$

415 nearby core (Lapointe, 2000a).

416

417

\section{Conclusion}

The diatom record shows that the major well-known climatic periods of the last $19 \mathrm{ka}$ were in fact part of a sequence. H1 (and consecutive oceanographic changes) and the YD were multiphase cold events initiallydescribed by common diatom assemblages: ice related

422 diatomsfollowed by the outstanding contribution of $O$. aurita. The two steps release of icebergs during $\mathrm{H} 1$ had a strong cooling effect that promoted the development of sea-ice.

Between $\mathrm{H} 1$ and the YD, the formation and melting of sea-ice played an important role, with melting sea-ice preceding the warm Bølling and attenuating the initial warming. This warm period, as the Allerød, was clearly indicated by the highest rates of warm water diatoms of the

427 deglacial record. The interruption of the warming between the Bølling and the Allerød 428 represents the Older Dryas ( $\sim 14$ cal kyr BP). The YD was announced by a long cooling trend initiated during the mid-Allerød. The YD started at $\sim 12.8 \mathrm{cal}$ kyr BP and had two main phases: until $12.42 \mathrm{cal}$ kyr BP, when some IRD are still found in the sediments and the conditions

431 dominated by sea-ice; and a second phase marked by a strong seasonal contrast since the 432 presence of a thin seasonal sea-ice is accompanied by the increased contribution ofwarm 
water diatoms. Although the dominant diatom species of this period (D. confervacea) can tolerate low salinity water, there is no clear evidence for a massive surface freshening. Our records highlight the importance of sea-ice during the last $19 \mathrm{ka}$ and the role of surficial low-salinity water in modulating the intensity of the warming. The spatial and temporal extent of sea-ice in the North Atlantic, and its melting, remain important in understanding how climate system recovers from such abrupt coolings or salinity anomalies.

Keywords: deglaciation;sea-ice;North Atlantic; diatom; Heinrich Event 1; Younger Dryas; Bølling-Allerød; Older Dryas; Preboreal

\section{Figure captions}

Table 1:Factors score matrix and corresponding variance from GGC14 diatom assemblages

Figure 1: Location of core GGC14 and modern surface water distribution in the region of the Grand Banks of Newfoundland after Pickart et al. (1999)and Petrie and Anderson(1983). Cold and warm currents are represented by dashedand plainarrows respectively.

Figure 2:GGC14 age-depth modeling obtained with CLAM 2.2 R package (Blaauw, 2010). Points on the curve and error bars represent AMS dates on planktonic foraminifera calibrated to calendar years assuming the standard 400 year reservoir effect and calibration probability. Grey area illustrates the $95 \%$ probability range.

Figure 3: General paleoceanographic data from GGC14 versus time: A-Factor 1 / ice; BFactor 2 /very cold; C- Factor 3 / coastal-temperate; D- Factor 4 / warm; E-Factor 5 / cool; FLow salinity diatoms (in \%); G- Total diatom abundance (number of valves per gram): 
median (line) and maximum and minimum values (dots); H- IRD (>150 $\mu \mathrm{m})$ abundances in

459 number of grains per gram; I-N. pachyderma (s) calcification temperature - CT in ${ }^{\circ} \mathrm{C}$ (Obbink

460 et al., 2010); J- Abundance of $N$. pachyderma (s) (in \%); K- $\delta^{18} \mathrm{O}$ (in \%o) of $N$. pachyderma (s)

461 (Keigwin et al., 2005); L- $\delta^{18} \mathrm{O}$ of NGRIP ice core (in \%o) (Rasmussen et al., 2006). The

462 dotted box indicates the red-clay sediments. Arrows on the age scale indicate $\mathrm{AMS}^{14} \mathrm{C}$ dates

463 and the grey numbers their depth $(\mathrm{cm})$.

464

465 Figure 4: GGC14 diatom species contribution (in \%) versus time: A- Fragilariopsis oceanica;

466 B- Delphineis surirella; C- Thalassiosira antarctica var. borealis/gravida resting spores; D-

467 Odontella aurita; E-Paralia sulcata; F-Thalassionema nitzschioides; G- Thalassiosira

468 oestrupii; H- Detonula confervacea.The dotted box indicates the red-clay sediments. Arrows

469 on the age scale indicate AMS ${ }^{14} \mathrm{C}$ dates and the grey numbers their depth $(\mathrm{cm})$.

470

471 Figure 5: Remaining GGC14 diatom species with a contribution $>2 \%$ in more than one

472 sample versus time. Only Heinrich event 1, the Bølling-Allerød, the Younger Dryas and the 473 Preboreal (PB) are indicated.

474

475 Figure 6: GGC14 semi-quantitative estimate of IRD composition (in \%): A- quartz grains; B-

476 detrital carbonate grains with the asterisks indicating rare occurrence $(<5 \%)$; C- hematite

477 stained quartz grains; D- IRD $(>150 \mu \mathrm{m})$ abundance (IRD/g).

478

479 Acknowledgements

480 This research is a contribution to the Fundação para a Ciência e Tecnologia - FCT project

481 MONA (PTDC/AAC-AMB/108449/2008) managed by CIIMAR (Interdisciplinary Centre of

482 Marine and Environmental Research, Porto, Portugal) and partially hosted by LNEG (The 
483 National Laboratory for Energy and Geology, Alfragide, Portugal). Financial support was

484 provided by FCT to IMG through postdoctoral fellowships (BPD/27214/2006 and

485 BPD/877185/2012)and thePOPH/FSE program. This research was also partially supported by

486 the European Regional Development Fund (ERDF) through the COMPETE - Operational

487 Competitiveness Programme and national funds through FCT, under the project "PEst-

488 C/MAR/LA0015/2011. This work was also supported by NSF grant OCE0822854 to

489 LDK.Thanks to A. Inês for support in the sample preparation for diatom analysis at

490 LNEG.We finally also thank the reviewers for their constructivecomments and suggestions.

491

492

\section{References}

494 Aharon, P., 2003. Meltwater flooding events in the Gulf of Mexico revisited: implications for 495 rapid climate changes during the last deglaciation. Paleoceanography 18.

496

497 Andersen, C., Koç, N., Jennings, A., Andrews, J.T., 2004. Nonuniform response of the major 498 surface currents in the Nordic Seas to insolation forcing: Implications for the Holocene 499 climate variability. Paleoceanography 19, doi: 10.1029/2002PA000873.

Andrews, G.W., 1981. Revision of the diatom genus Delphineis and morphology of

502 Delphineis surirella (Ehrenberg) G. W. Andrews, n. comb., In: Ross, R. (Ed.), Proceedings of

503 the 6th Symposium on Recent and Fossil Diatoms. Koeltz, Koenigstein, pp. 81-90.

504

505 Baars, J.W.M., 1985. Autecological investigations on marine diatoms. 4: Biddulphia aurita

506 (Lyngb.) Brebisson et Godey-A succession of spring diatoms. Hydrobiological Bulletin 19, 507 109-116. 
509 Bakke, J., Lie, Ø., Heegaard, E., Dokken, T., Haug, G.H., Birks, H.H., Dulski, P., Nilsen, T.,

510 2009. Rapid oceanic and atmospheric changes during the Younger Dryas cold period. Nature

511 Geoscience, doi: 10.1038/NGEO1439.

512

513 Bard, E., Rostek, F., Turon, J.L., Gendreau, S., 2000. Hydrological impact of Heinrich events 514 in the subtropical northeast Atlantic. Science 289, 1321-1324.

515

516 Blaauw, M., 2010. Methods and code for 'classical' age-modelling of radiocarbon sequences.

517 Quaternary Geochronology 5, 512-518.

518

519 Bond, G., Heinrich, H., Broecker, W., Labeyrie, L., McManus, J., Andrews, J., Huon, S.,

520 Jantschik, R., Clasen, S., Simet, C., Tedesco, K., Klas, M., Bonani, G., Ivy, S., 1992.

521 Evidence for massive discharges of icebergs into the North Atlantic ocean during the last

522 glacial period. Nature 360, 245-249.

523

524

525

526

527

528 Broecker, W.S., Denton, G.H., Edwards, R.L., Cheng, H., Alley, R.B., Putnam, A.E., 2010.

529 Putting the Younger Dryas cold event into context. Quaternary Science Reviews 29, 1078-

530 1081. 
532 Broecker, W.S., Kennett, J.P., Flower, B.P., Teller, J.T., Trumbore, S., Bonani, G., Wolfli,

533 W., 1989. Routing of meltwater from the Laurentide Ice Sheet during the Younger Dryas cold

534 episode. Nature 341, 318-321.

535

536 Carlson, A.E., Clark, P.U., Haley, B.A., Klinkhammer, G.P., Simmons, K., Brook, E.J.,

537 Meissner, K.J., 2007. Geochemical proxies of North American freshwater routing during the

538 Younger Dryas cold event. P Natl Acad Sci USA 104, 6556-6561.

539

540 Chiang, J.C.H., Bitz, C.M., 2005. Influence of high latitude ice cover on the marine

541 Intertropical Convergence Zone. Climate Dynamics 25, 477-496.

542

543 Cole, J.M., Goldstein, S.L., deMenocal, P.B., Hemming, S.R., Grousset, F.E., 2009.

544 Contrasting compositions of Saharan dust in the astern Atlantic Ocean during the last

545 deglaciation and African Humid Period. Earth Planet Sc Lett 278, 257-266.

546

547 Condron, A., Winsor, P., 2011. A subtropical fate awaited freshwater discharged from glacial 548 Lake Agassiz. Geophysical Research Letters 38, doi:10.1029/2010GL046011.

549

550 De Sève, M.A., 1999. Transfer function between surface sediment diatom assemblages and

551 sea-surface temperature and salinity of the Labrador Sea. Marine Micropaleontology 36, 249-

552267.

553

554 deGelleke, L., Hill, P.S., Kienast, M., Piper, D.J., 2013. Sediment dynamics during Heinrich

555 event H1 inferred from grain size. Marine Geology 336, 160-169.

556 
Denton, G.H., Broecker, W.S., Alley, R. B., 2006. The Mystery Interval 17.5 to 14.5 kyrs

558 ago. Pages News 14, 14-16.

559

560 Deschamps, P., Durand, N., Bard, E., Hamelin, B., Camoin, G., Thomas, A.L., Henderson,

561 G.M., Okuno, J.i., Yokoyama, Y., 2012. Ice-sheet collapse and sea-level rise at the Bølling

562 warming 14,600 years ago. Nature $483,-556459$.

563

564 deVernal, A., HillaireMarcel, C., Bilodeau, G., 1996. Reduced meltwater outflow from the

565 laurentide ice margin during the Younger Dryas. Nature 381, 774-777.

566

567 Dickson, R., Lazier, J., Meincke, J., Rhines, P., Swift, J., 1996. Long-term coordinated

568 changes in the convective activity of the North Atlantic. Progress in Oceanography 38, 241569295.

570

571

Dyke, A.S., 2004. An outline of North American Deglaciation with emphasis on central and

572

northern Canada. Developments in Quaternary Sciences, 371-406.

573

574 Flower, B., Kennett, J., 1990. The Younger Dryas cool episode in the Gulf of Mexico.

575 Paleoceanography 5, 949-961.

576 Flückiger, J., Knutti, R., White, J.W.C., 2006. Oceanic processes as potential trigger and

577 amplifying mechanisms for Heinrich events. Paleoceanography 21,

578 doi:10.1029/2005PA001204.

579

580 Galehouse, J.S., 1971. Point counting, In: Carver, R.E. (Ed.), Procedures in sedimentary

581 petrology. Wiley-Interscience, New-York, pp. 385-407. 
583 Gatien, G., 1976. A study of the Slope Water region south of Halifax. Journal of the Fisheries 584 Research Board of Canada 33, 2213-2217.

585

586 Gil, I.M., Keigwin, L.D., Abrantes, F., 2010. Comparison of diatom records of the Heinrich 587 event 1 in the Western North Atlantic iop conference series earth and environmental science, 588 doi: $10.1088 / 1755-1315 / 1089 / 1081 / 012008$.

589

590 Gil, I.M., Keigwin, L.D., Abrantes, F.G., 2009. Deglacial diatom productivity and surface 591 ocean properties over the Bermuda Rise, northeast Sargasso Sea. Paleoceanography 24, 592 doi:10.1029/2008PA001729.

593

594 Guillard, R.R.L., Ryther, J.H., 1962. Studies of marine planktonic diatoms I. Cyclotella nana 595 Hustedt, and Detonula confervacea (Cleve) Gran. Canadian Journal of Microbiology 8, 229596239.

597

Hald, M., Hagen, S., 1998. Early Preboreal cooling in the Nordic seas region triggered by 599 meltwater. Geology 26, 615-618.

600

601 Hasle, G.R., 1973. Some marine plankton genera of the diatom family Thalassiosiraceae. 602 Nova Hedwigia Beiheft 45, 1-49.

603

604 Hasle, G.R., Syvertsen, E.E., Steidinger, K.A., Tangen, K., 1996. Marine diatoms, In: Tomas, 605 C.R. (Ed.), Identifying marine diatoms and dinoflagellates. Academic Press, Inc., San Diego, 606 p. 598. 
608 Heinrich, H., 1988. Origin and Consequences of Cyclic Ice Rafting in the Northeast Atlantic 609 Ocean during the Past 130,000 Years. Quaternary Research 29, 142-152.

610

611 Hemming, S.R., 2004. Heinrich events: Massive late pleistocene detritus layers of the North 612 Atlantic and their global climate imprint. Rev Geophys 42, doi:10.1029/2003RG000128.

613

614 Hendey, N.I., 1964. An introductory Account of the smaller algae of British Coastal Waters. 615 Otto Koeltz Science, London.

616

617 Hillaire-Marcel, C., de Vernal, A., 2008. Stable isotope clue to episodic sea ice formation in 618 the glacial North Atlantic. Earth Planet Sc Lett 268, 143-150.

619

620 Holt, M.G., Smayda, T.J., 1974. The effect of daylight and light intensity on the growth rate 621 of the marine diatom Detonula confervacea (Cleve) Gran. Journal of Phycology 10, 231-237. 622

623 Ikeya, T., Kikuchi-Kawanobe, K., Kudoh, S., 2001. Floristic examination of diatom 624 assemblage in the dim light-environment of water column and sea ice, Saroma Ko lagoon, 625 Hokkaido, Japan. Polar Bioscience 14, 33-44.

626

627 Imbrie, J., Kipp, N.G., 1971. A new micropaleontological method for quantitative 628 paleoclimatology: application to a late Pleistocene Caribbean core, In: Turekian, K.K. (Ed.), 629 Late Cenozoic Glacial Ages. Yale Univ. Press, New Haven, Conn., pp. 71-181. 630 
631 Jiang, H., Seidenkrantz, M.S., Knudsen, K.L., Eiríksson, J., 2001. Diatom surface sediment

632 assemblages around Iceland and their relationships to oceanic environmental variables.

633 Marine Micropaleontology 41, 73-96.

634

635 Jongma, J.I., Renssen, H., Roche, D.M., 2012. Simulating Heinrich event 1 with interactive 636 icebergs. Climate Dynamics, doi: 10.1007/s00382-00012-01421-00381.

637

638 Justwan, A., Koç, N., 2008. A diatom based transfer function for reconstructing sea ice 639 concentrations in the North Atlantic. Marine Micropaleontology 66, 264-278.

640

641 Kaufman, D.S., Miller, G.H., Stravers, J.A., Andrews, J.T., 1993. Abrupt early Holocene (9.9-

$6429.6 \mathrm{ka}$ ) ice-stream advance at the mouth of Hudson Strait, Arctic Canada. Geology 21, $1063-$ 6431066.

644

645 Keigwin, L.D., Jones, G.A., 1995. The marine record of deglaciation from the continental 646 margin off Nova Scotia. Paleoceanography 10, 973-985.

647

648 Keigwin, L.D., Sachs, J.P., Rosenthal, Y., Boyle, E.A., 2005. The 8200 year BP event in the 649 slope water system, western subpolar North Atlantic. Paleoceanography 20, 650 doi:10.1029/2004PA001074.

651

652 Kelley, S.E., Briner, J.P., Young, N.E., 2013. Rapid ice retreat in Disko Bugt supported by 10

653 Be dating of the last recession of the western Greenland Ice Sheet. Quaternary Science

654 Reviews 82, 13-22.

655 
656 Knudsen, K.L., Jiang, H., Jansen, E., Eiríkson, J., Heinemeier, J., Seidenkrantz, M.-S., 2004.

657 Environmental changes off North iceland during the deglaciation and the Holocene:

658 foraminifera, diatoms and stable isotopes. Marine Micropaleontology 50, 273-305.

659

660 Koç Karpuz, N., Jansen, E., 1992. A high-resolution diatiom record of the last deglaciation

661 from the SE Norwegian Sea: documentation of rapid climatic changes. Paleoceanography 7, $662499-520$.

663

664 Koç Karpuz, N., Schrader, H., 1990. Surface sediment diatom distribution and Holocene 665 paleotemperature variations in the Greenland, Iceland and Norwegian Sea. Paleoceanography $666 \quad 5(4), 557-580$.

667

668 Koç, N., Jansen, E., Haflidason, H., 1993. Paleoceanographic reconstructions of surface ocean 669 conditions in the Greenland, Iceland and Norwegian seas through the last 14 ka based on 670 diatoms. Quaternary Science Reviews 12, 115-140.

671

672 Kohly, A., 1998. Diatom flux and species composition in the Greenland Sea and the 673 Norwegian Sea in 1991-1992. Marine Geology 145, 293-312.

674

675 Kozdon, R., Eisenhauer, A., Weinelt, M., Meland, M.Y., Nürnberg, D., 2009. Reassessing

$676 \mathrm{Mg} / \mathrm{Ca}$ temperature calibrations of Neogloboquadrina pachyderma (sinistral) using paired $677 \delta 44 / 40 \mathrm{Ca}$ and $\mathrm{Mg} / \mathrm{Ca}$ measurements. Geochemistry, Geophysics, Geosystems 10. 678 
679

680

681

682

683

684

685

686

687

688

689

690

691

692

693

694

695

696

697

698

699

700

701

702

Lapointe, M., 2000a. Late Quaternary paleohydrology of the Gulf of St. Lawrence (Quebec, Canada) based on diatom analysis. Palaeogeography, Palaeoclimatology, Palaeoecology 156, 261-276.

Lapointe, M., 2000b. Modern diatom assemblages in surface sediments from the Maritime Estuary and the Gulf of St. Lawrence, Québec (Canada). Marine Micropaleontology 40, 4365.

Lea, D.W., Pak, D.K., Peterson, L.C., Hughen, K.A., 2003. Synchroneity of tropical and highlatitude Atlantic temperatures over the Last Glacial Termination. Science 301, 1361-1364.

Levac, E., Lewis, M., Stretch, V., Duchesne, K., Neulieb, T., 2015. Evidence for meltwater drainage via the St. Lawrence River Valley in marine cores from the Laurentian Channel at the time of the Younger Dryas. Global and Planetary Change 130, 47-65.

Levine, R.C., Bigg, G.R., 2008. Sensitivity of the glacial ocean to Heinrich events from different iceberg sources, as modeled by a coupled atmosphere-iceberg-ocean model. Paleoceanography 23, doi:10.1029/2008PA001613.

Liu, Z., Otto-Bliesner, B.L., He, F., Brady, E.C., Tomas, R., Clark, P.U., Carlson, A.E., Lynch-Stieglitz, J., Curry, W., Brook, E., Erickson, D., Jacob, R., Kutzbach, J., Cheng, J., 2009. Transient simulation of last deglaciation with a new mechanism for Bølling-Allerød warming. Science 325, 310-314. 
Mangerud, J., Andersen, S.T., Berglund, B.E., Donner, J.J., 1974. Quaternary stratigraphy of

704 Norden, a proposal for terminology and classification. Boreas 3, 109-126.

705

706 Marchitto, T.M., Wei, K.-Y., 1995. History of Laurentide meltwater flow to the Gulf of

707 Mexico during the last deglaciation, as revealed by reworked calcareous nannofossils.

708 Geology 23, 779-782.

709

710 Maynard, N.G., 1976. Relationship between diatoms surface sediments of the Atlantic Ocean

711 and the biological response and physical oceanography of overlying waters. Paleobiology 2,

$71299-121$.

713

714 McMinn, A., Hattori, H., Hirawake, T., Iwamoto, A., 2008. Preliminary investigation of

715 Okhotsk Sea ice algae; taxonomic composition and photosynthetic activity. Polar Biol 31, $716 \quad 1011-1015$.

717

718 McQuoid, M.R., 2005. Influence of salinity on seasonal germination of resting stages and

719 composition of microplankton on the Swedish west coast. Marine Ecology Progress Series $720 \quad 289,151-163$.

721

722 McQuoid, M.R., Hobson, L.A., 1996. Diatom resting stages. Journal of Phycology 32, 889723902.

724 Medlin, L.K., Priddle, J., 1990. Polar Marine Diatoms. British Antarctic Survey, Cambridge, 725 UK.

726 
730

731

732

733

734

735

736

737

738

739

740

741

742

743

744

745

746

747

748

749

750

751

Meland, M.Y., Jansen, E., Elderfield, H., Dokken, T.M., Olsen, A., Bellerby, R.G., 2006.

$\mathrm{Mg} / \mathrm{Ca}$ ratios in the planktonic foraminifer Neogloboquadrina pachyderma (sinistral) in the northern North Atlantic/Nordic Seas. Geochemistry, Geophysics, Geosystems 7.

Melnikov, I.A., Kolosova, E.G., Welch, H.E., Zhitina, L.S., 2002. Sea ice biological communities and nutrient dynamics in the Canada Basin of the Arctic Ocean. Deep-Sea Research I 49, 1623-1649.

Miller, G.H., Kaufman, D.S., 1990. Rapid fluctuations of the Laurentide Ice Sheet at the mouth of Hudson Strait: New evidence for ocean/ice-sheet interactions as a control on the Younger Dryas. Paleoceanography 5, 907-919.

Naughton, F., Goni, M.F.S., Kageyama, M., Bard, E., Duprat, J., Cortijo, E., Desprat, S., Malaize, B., Joly, C., Rostek, F., Turon, J.L., 2009. Wet to dry climatic trend in north-western Iberia within Heinrich events. Earth Planet Sc Lett 284, 329-342.

Neugebauer, I., Brauer, A., Dräger, N., Dulski, P., Wulf, S., Plessen, B., Mingrama, J., Herzschuh, U., Brande, A., 2012. A Younger Dryas varve chronology from the Rehwiese palaeolake record in NE-Germany Quaternary Science Reviews 36, 91-102.

Obbink, E.A., Carlson, A.E., Klinkhammer, G.P., 2010. Eastern North American freshwater discharge during the Bølling-Allerød warm periods. Geology 38, 171-174.

Ohashi, K., Sheng, J., 2013. Influence of St. Lawrence River discharge on the circulation and hydrography in Canadian Atlantic waters. Continental Shelf Research 58, 32-49. 
753 Pearce, C., Seidenkrantz, M.-S., Kuijpers, A., Massé, G., Reynisson, N.F., Kristiansen, S.M., 754 2013. Ocean lead at the termination of the Younger Dryas cold spell. Nature Communications $7554,1664$.

756

757 Pearce, C., Seidenkrantz, M.-S., Kuijpers, A., Reynisson, N.F., 2014. A multi-proxy

758 reconstruction of oceanographic conditions around the Younger Dryas-Holocene transition in 759 Placentia Bay, Newfoundland. Marine Micropaleontology 112, 39-49.

760

761

Petrie, B., Anderson, C., 1983. Circulation on the Newfoundland continental shelf.

762 Atmosphere-Ocean 21, 207-226.

763

764 Pickart, R.S., McKee, T.K., Torres, D.J., Harrington, S.A., 1999. Means structure and 765 interannual variability of the Slopewater system South of Newfoundland. Journal of Physical 766 Oceanography 29, 2541-2558.

767

Piper, D.J.W., Skene, K.I., 1998. Latest Pleistocene ice-rafting events on the Scotian Margin (eastern Canada) and their relationship to Heinrich events. Paleoceanography 13, 205-214.

770

Poore, R., Dowsett, H., Verardo, S., Quinn, T.M., 2003. Millennial-to century-scale

772 variability in Gulf of Mexico Holocene climate records. Paleoceanography 18.

773

774 Prange, M., Lohmann, G., Romanova, V., Butzin, M., 2004. Modelling tempo-spatial

775 signatures of Heinrich Events: influence of the climatic background state. Quaternary Science 776 Reviews 23, 521-527. 
778 R core team, 2013. R: A language and environment for statistical computing. R Foundation 779 for Statistical Computing, Vienna, Austria.

780

781 Rahmstorf, S., 2002. Ocean circulation and climate during the past 120,000 years. Nature 419, $782 \quad 207-214$.

783

784 Rasmussen, S.O., Andersen, K.K., Svensson, A.M., Steffensen, J.P., Vinther, B.M., Clausen, 785 H.B., Siggaard-Andersen, M.-L., Johnsen, S.J., Larsen, L.B., Dahl-Jensen, D., Bigler, M., 786 Röthlisberger, R., Fischer, H., Goto-Azuma, K., Hansson, M.E., Ruth, U., 2006. A new

787 Greenland ice core chronology for the last glacial termination. Journal of Geophysical 788 Research 111, doi: 10.1029/2005JD006079.

789

Rasmussen, T., Thomsen, E., 2012. Changes in planktic foraminiferal faunas, temperature and 791 salinity in the Gulf Stream during the last 30,000 years: influence of meltwater via the 792 Mississippi River. Quaternary Science Reviews 33, 42-54.

793

794 Reimer, P.J., Bard, E., Bayliss, A., Beck, J.W., Blackwell, P.G., Bronk Ramsey, C., Buck, 795 C.E., Cheng, H., Edwards, R.L., Friedrich, M., Grootes, P.M., Guilderson, T.P., Haflidason, 796 H., Hajdas, I., Hatté, C., Heaton, T.J., Hoffmann, D.L., Hogg, A.G., Hughen, K.A., Kaiser, 797 K.F., Kromer, B., Manning, S.W., Niu, M., Reimer, R.W., Richards, D.A., Scott, E.M., 798 Southon, J.R., Staff, R.A., Turney, C.S.M., van der Plicht, J., 2013. IntCal13 and Marine13

799 Radiocarbon Age Calibration Curves 0-50,000 Years cal BP. 800 
801 Robineau, B., Legendre, L., Kishino, M., Kudoh, S., 1997. Horizontal heterogeneity of

802 microalgal biomass in the first-year sea ice of Saroma-ko Lagoon (Hokkaido, Japan). Journal 803 of Marine Systems 11, 81-91.

804

805 Roche, D.M., Paillard, D., Caley, T., Waelbroeck, C., 2014. LGM hosing approach to

806 Heinrich Event 1: results and perspectives from data-model integration using water isotopes.

807 Quaternary Science Reviews 106, 247-261.

808

809 Romero, O.E., Kim, J.-H., Donner, B., 2008. Submillennial-to-millennial variability of diatom

810 production off Mauritania, NW Africa, during the last glacial cycle. Paleoceanography 23,

811 doi:10.1029/2008PA001601.

812

813 Sancettta, C., 1992. Primary production in the glacial North Atlantic and North Pacific

814 oceans. Nature 360, 249-251.

815

816 Shaw, J., Gareau, P., Courtney, R., 2002. Palaeogeography of Atlantic Canada 13-0kyr.

817 Quaternary Science Reviews 21, 1861-1878.

818

819 Shaw, J., Piper, D., Fader, G., King, E., Todd, B., Bell, T., Batterson, M., Liverman, D., 2006.

820 A conceptual model of the deglaciation of Atlantic Canada. Quaternary Science Reviews 25, $821 \quad 2059-2081$.

822

823 Smayda, T.J., 1958. Biogeographical studies of marine phytoplankton. Oikos 9, 158-191. 824 
825 Stabell, B., 1986. Variations of diatom flux in the eastern equatorial Atlantic during the last 826 400,000 years ("METEOR" cores 13519 and 13521). Marine Geology 72, 305-323.

827

828 Stanford, J.D., Rohling, E.J., Hunter, S.E., Roberts, A.P., Rasmussen, S.O., Bard, E.,

829 McManus, J., Fairbanks, R.G., 2006. Timing of meltwater pulse 1a and climate responses to

830 meltwater injections. Paleoceanography 21, doi:10.1029/2006PA001340.

831

832 Syvertsen, E.E., 1977. Thalassiosira rotula and T. gravida: Ecology and morphology. Beiheft 833 zur Nova Hedwigia 54, 99-112.

834

835 Visbeck, M., 2002. The ocean's role in Atlantic climate variability. Science 297, 2223-2224.

836

837 Walden, J., Wadsworth, E., Austin, W.E.N., Peters, C., Scourse, J.D., Hall, I.R., 2006.

838 Compositional variability of ice-rafted debris in Heinrich layers 1 and 2 on the northwest

839 European continental slope identified by environmental magnetic analyses. Journal of

840 Quaternary Science 22, 163-172.

841 


\section{Table 1}

\begin{tabular}{|c|c|c|c|c|c|}
\hline Diatomspecies & Factor 1 & Factor 2 & Factor 3 & Factor 4 & Factor 5 \\
\hline Actinocyclusoctanarius & 0,010 & $-0,002$ & 0,026 & 0,004 & $-0,002$ \\
\hline Actinoptychussplendens & $-0,004$ & $-0,008$ & 0,0158 & 0,082 & 0,029 \\
\hline Azpeitia africana & $-0,002$ & 0,003 & 0,02 & $-0,003$ & $-0,002$ \\
\hline Azpeitianeocrenulata & $-0,006$ & $-0,015$ & 0,013 & 0,005 & $-0,038$ \\
\hline Azpeitianodulifera & $-0,007$ & $-0,003$ & 0,031 & 0,006 & $-0,006$ \\
\hline Bacteriosirafragilis (spore) & $-0,008$ & $-0,013$ & 0,058 & 0,020 & $-0,108$ \\
\hline Bacteriosirafragilis & 0,001 & $-0,004$ & 0,035 & 0,013 & $-0,076$ \\
\hline Coscinodiscusdivisus & 0,011 & $-0,004$ & 0 & $-0,003$ & $-0,0008$ \\
\hline Coscinodiscuskutzingii & 0,005 & $-0,021$ & 0,007 & $-0,006$ & 0,006 \\
\hline Coscinodiscusmarginatus & 0,024 & 0,005 & 0,049 & 0,019 & 0,035 \\
\hline Coscinodiscusradiatus & $-0,001$ & $-0,006$ & 0,012 & 0,003 & $-0,008$ \\
\hline Delphineissurirella & 0,416 & $-0,026$ & 0,028 & 0,237 & 0,672 \\
\hline Detonulaconfervacea & 0,017 & $-0,018$ & 0,067 & $-0,001$ & $-0,561$ \\
\hline Fragilariopsiscylindrus & 0,02 & 0,003 & 0,0006 & 0,001 & $-0,005$ \\
\hline Fragilariopsisdoliolus & $-0,021$ & $-0,026$ & 0,056 & 0,031 & $-0,093$ \\
\hline Fragilariopsislinearis & 0,004 & 0,002 & 0,003 & 0,001 & 0,0007 \\
\hline Fragilariopsisoceanica & $\mathbf{0 , 8 8 5}$ & 0,029 & 0,082 & $-0,006$ & $-0,351$ \\
\hline Fragilariopsissublinearis & 0,055 & 0,002 & 0,009 & $-0,0004$ & 0,032 \\
\hline Odontella aurita & $-0,048$ & $-0,614$ & 0,007 & 0,045 & $-0,069$ \\
\hline Paraliasulcata & 0,042 & 0,042 & 0,918 & $-0,008$ & 0,033 \\
\hline Porosiraglacialis & 0,01 & 0,005 & 0,013 & 0,005 & $-0,017$ \\
\hline Rhizosoleniabergonii & $-0,006$ & 0,004 & 0,039 & 0,015 & $-0,016$ \\
\hline Rhizosoleniasetigera & $-0,002$ & 0,0008 & 0,018 & $-0,001$ & $-0,005$ \\
\hline Rhizosolenia simplex & $-0,002$ & 0,002 & 0,018 & $-0,002$ & $-0,003$ \\
\hline Rhizosoleniastyliformis & $-0,003$ & $-0,007$ & 0,035 & $-0,008$ & $-0,027$ \\
\hline Rhizosoleniaspp & 0,0009 & 0,007 & 0,125 & $-0,016$ & 0,004 \\
\hline Roperiatesselata & $-0,011$ & $-0,015$ & 0,045 & 0,037 & $-0,030$ \\
\hline Thalassionemanitzschioides & 0,026 & 0,014 & 0,31 & 0,155 & $-0,111$ \\
\hline Thalassiosiraaff. constricta & 0,07 & $-0,01$ & 0,003 & $-0,001$ & 0,077 \\
\hline Thalassiosiraangulata & 0,08 & 0,012 & 0,044 & 0,079 & 0,104 \\
\hline Thalassiosiraanguste-lineata & $-0,018$ & $-0,061$ & 0,008 & 0,038 & $-0,082$ \\
\hline borealis & 0,002 & 0,007 & 0,005 & 0,004 & $-0,012$ \\
\hline Thalassiosira eccentrica & 0,009 & $-0,023$ & 0,049 & 0,043 & $-0,002$ \\
\hline Thalassiosiraferelineata & $-0,003$ & 0,0005 & 0,0003 & 0,036 & $-0,028$ \\
\hline $\begin{array}{l}\text { Thalassiosira } \\
\text { gravida/antárctica var. } \\
\text { borealis (spore) }\end{array}$ & 0,051 & $-0,775$ & 0,034 & 0,040 & 0,031 \\
\hline Thalassiosira gravida & 0,044 & 0,0004 & 0,036 & 0,028 & $-0,038$ \\
\hline Thalassiosirahyalina & 0,04 & 0,003 & 0,004 & 0,013 & $-0,011$ \\
\hline Thalassiosiralineata & $-0,007$ & $-0,026$ & 0,022 & 0,034 & $-0,076$ \\
\hline Thalassiosiranordenskioeldii & 0,019 & $-0,043$ & 0,025 & 0,0457 & 0,007 \\
\hline Thalassiosiraoestrupii & $-0,11$ & 0,076 & 0,063 & 0,942 & $-0,146$ \\
\hline Thalassiosiraspp & 0,014 & $-0,045$ & 0,0003 & 0,004 & 0,046 \\
\hline Thalassiotrixlongissima & 0,019 & $-0,006$ & 0,025 & 0,014 & 0,019 \\
\hline variance & 65,47 & 11,76 & 6,44 & 5 & 3,56 \\
\hline cumulative & - & 77,23 & 83,67 & 88,67 & 92,23 \\
\hline
\end{tabular}




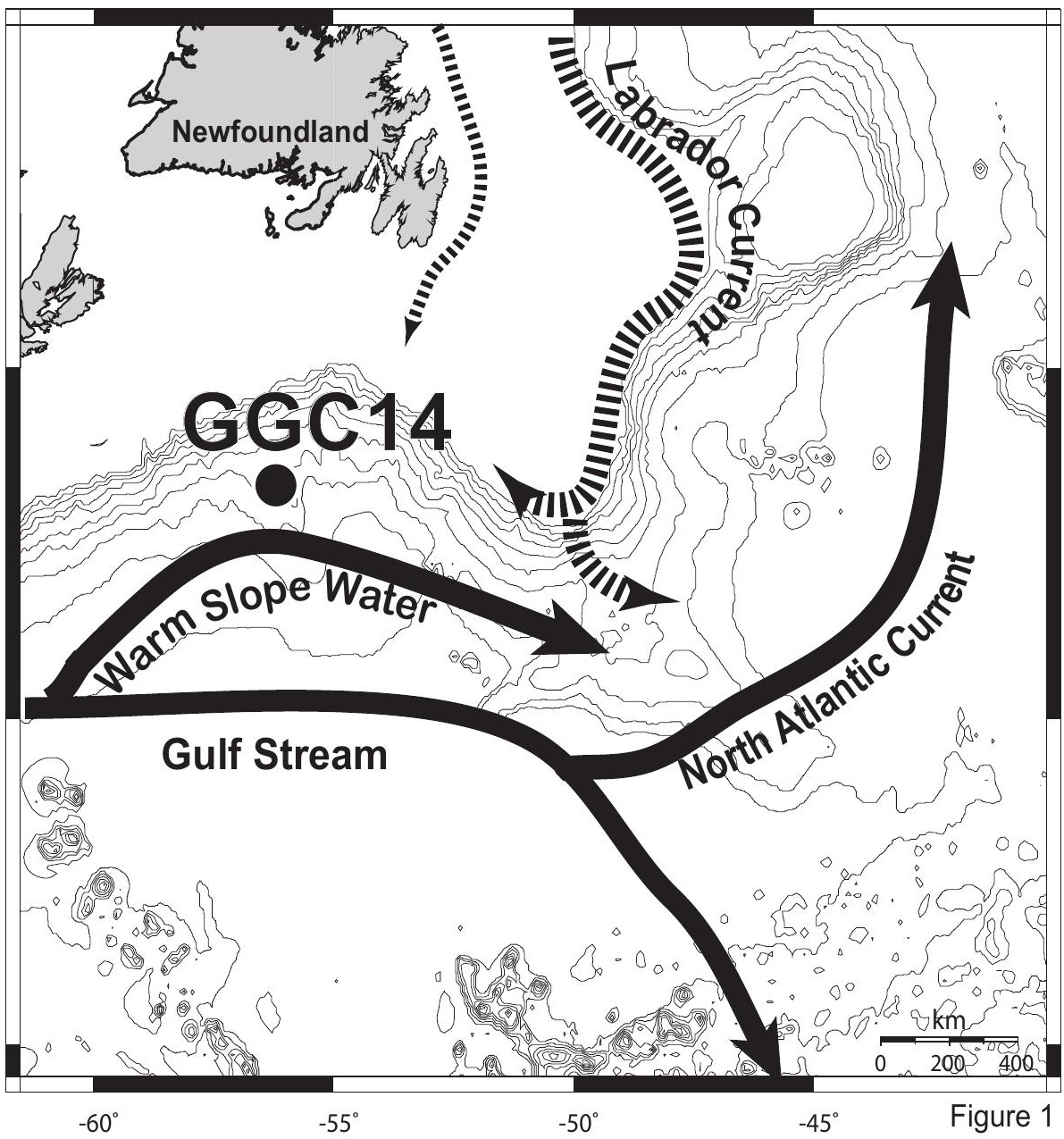


Figure 2

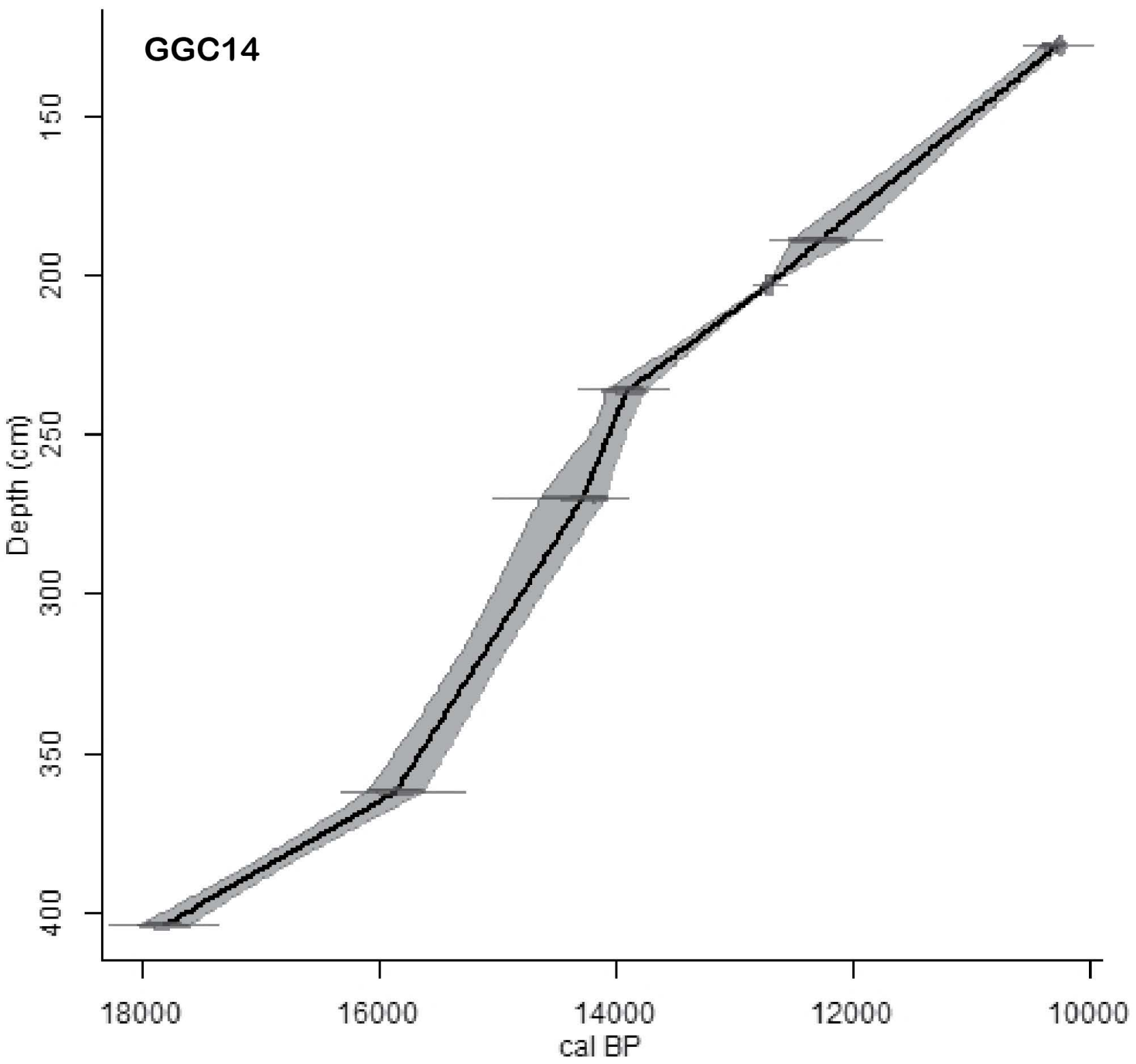




\section{Figure 3}

\section{Younger}

Allerød Bølling Heinrich 1

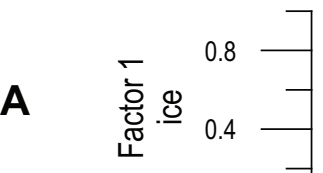

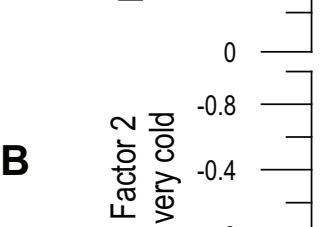

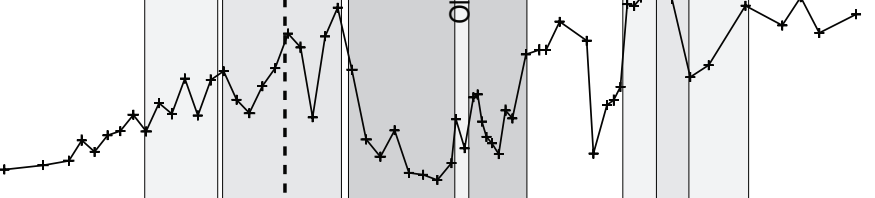

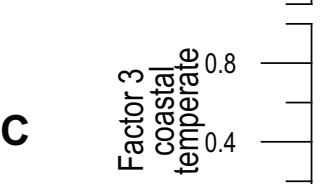

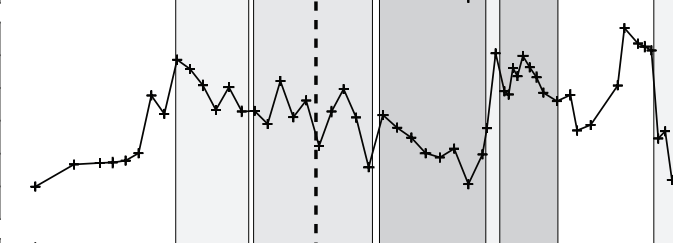

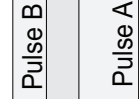

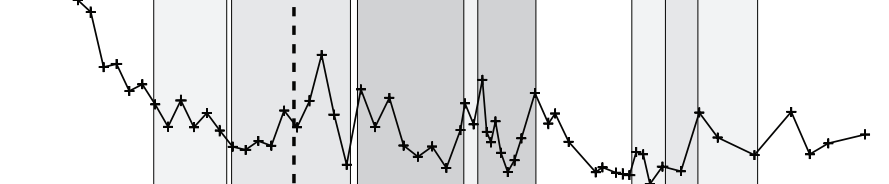

部艁

0
0.8

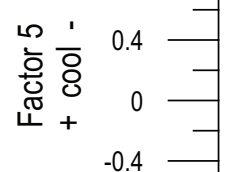
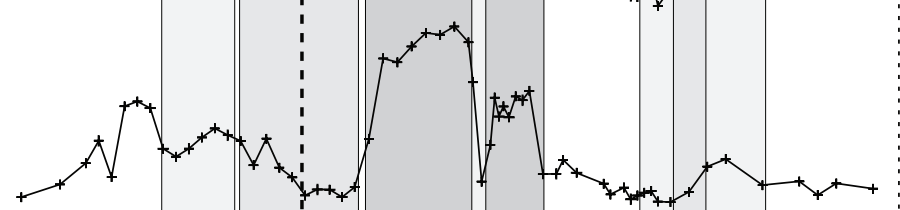

F

F

6

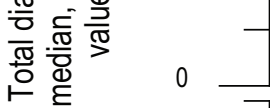

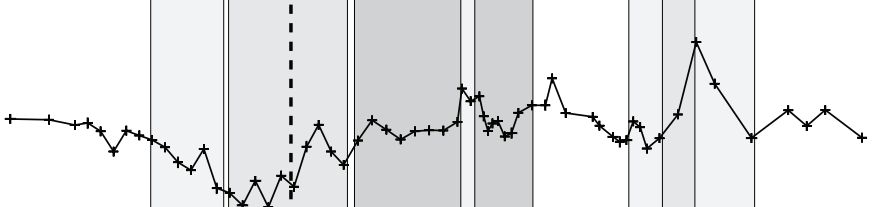

H$$
\text { 这要 }
$$

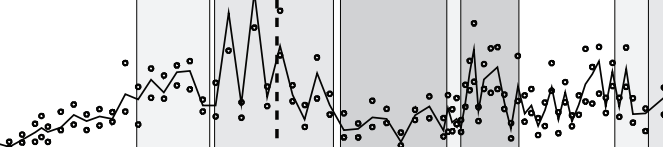

$\because \% 0 \%$

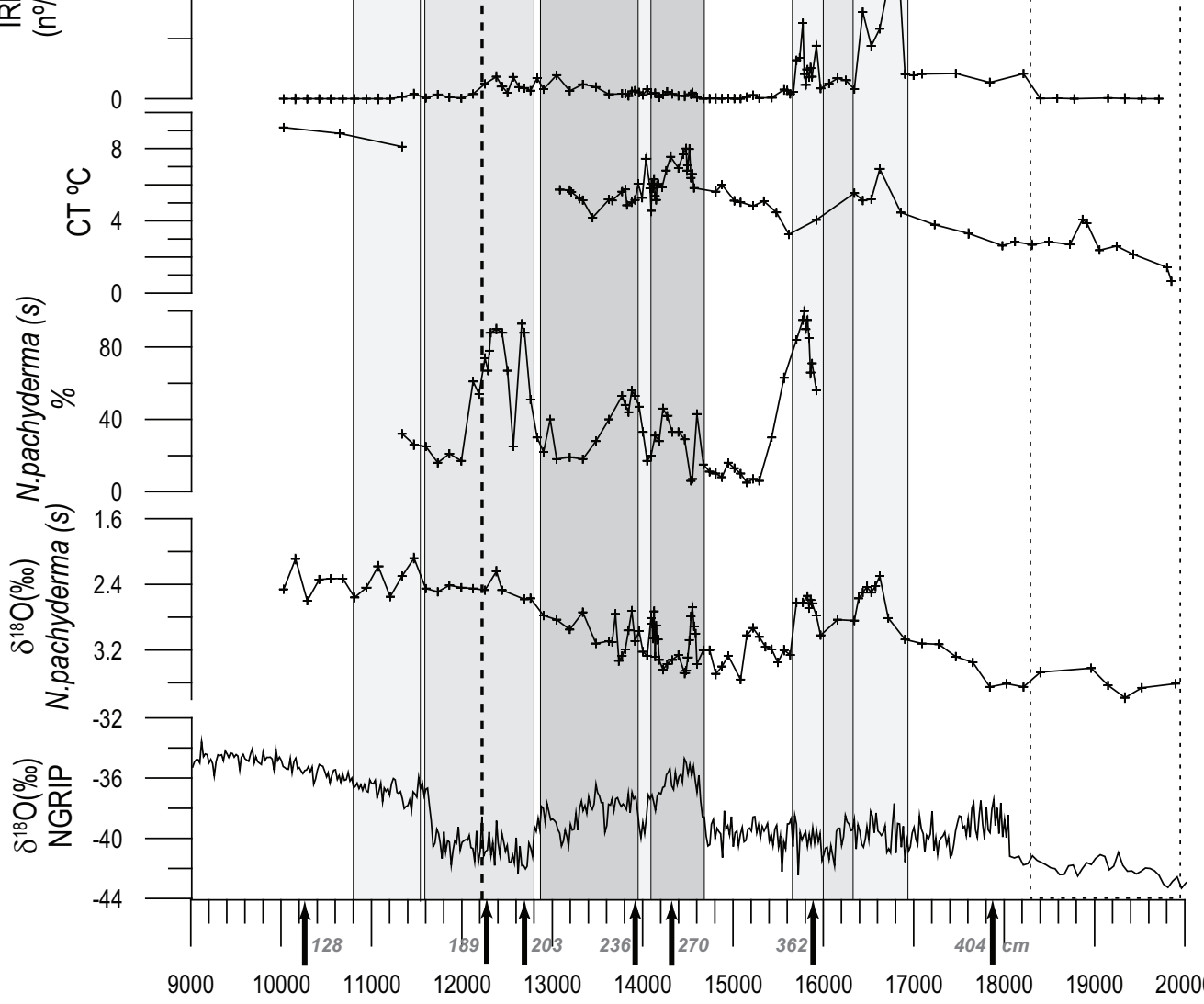


Figure 4

\section{Younger}

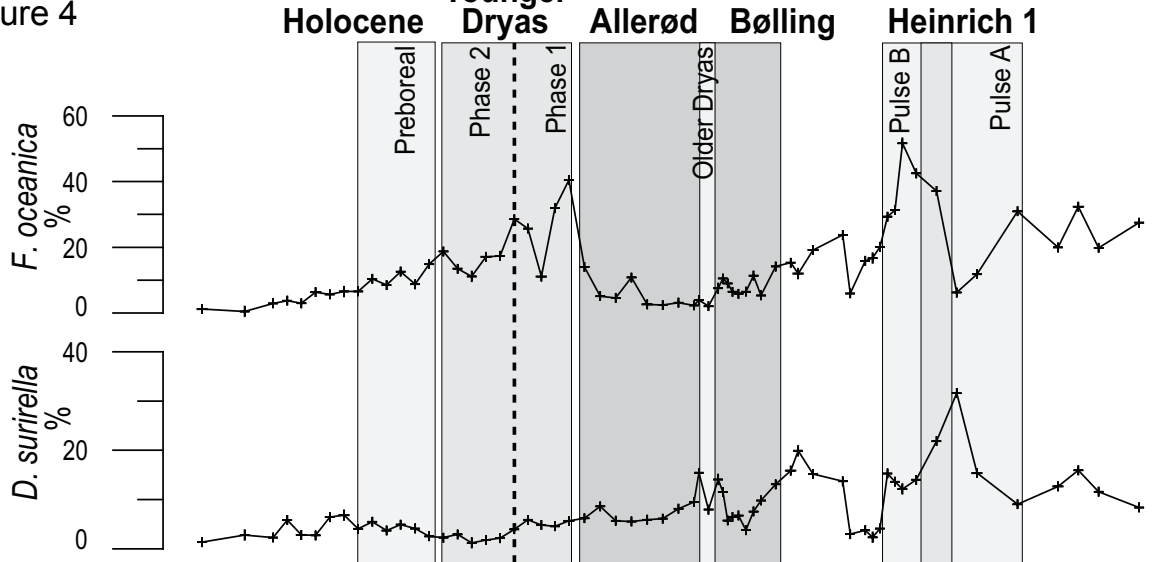

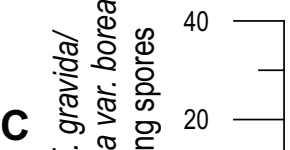

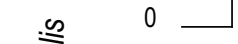

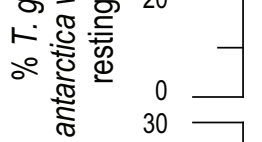
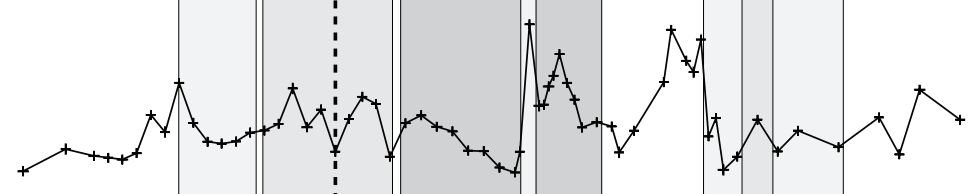

D 縍

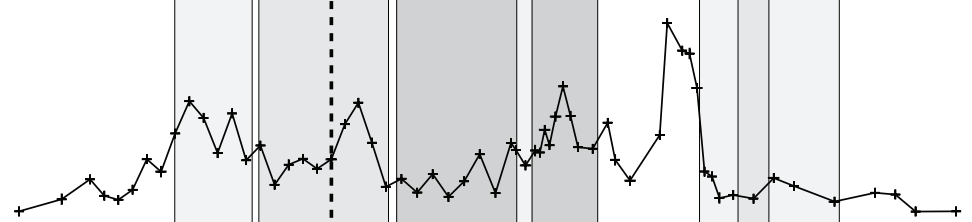

E

$0_{10}^{\circ}$

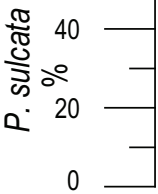

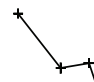

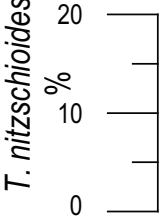
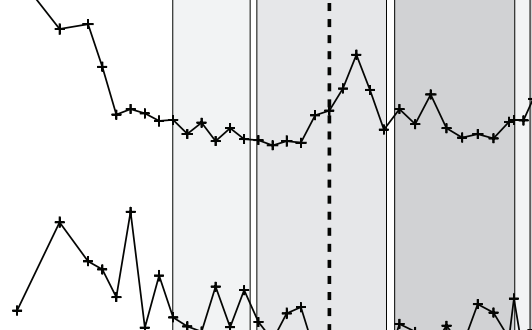

H

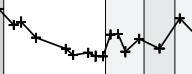

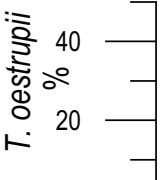

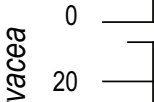

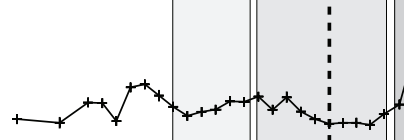

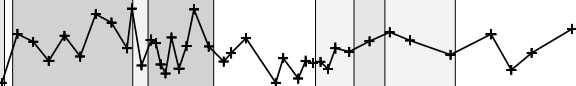

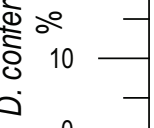

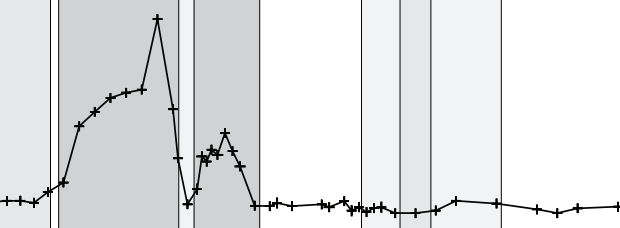




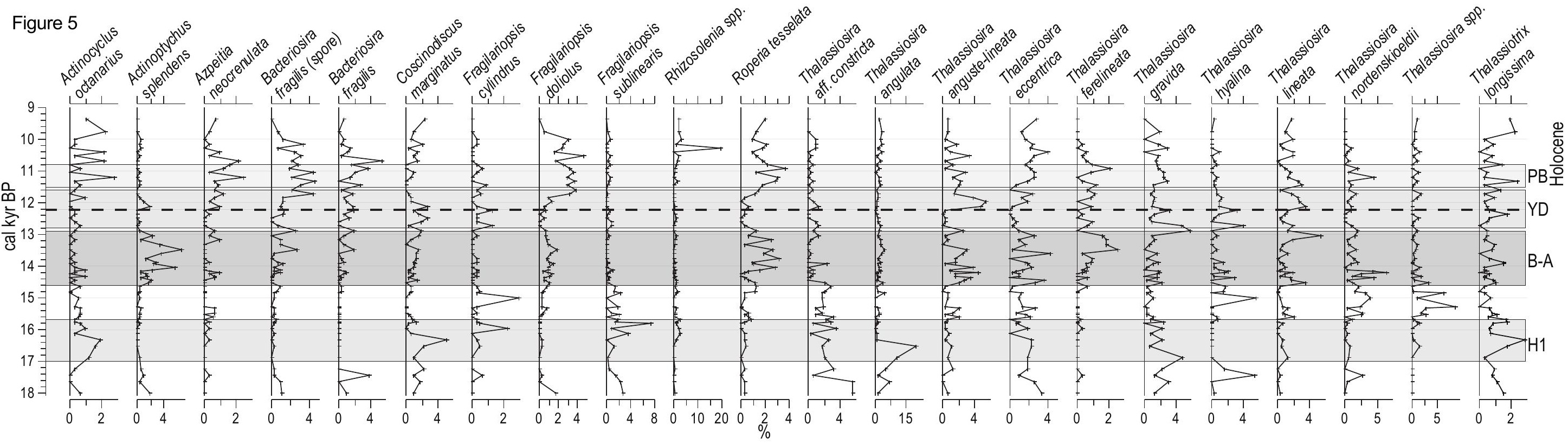


